\title{
Kene tutunması sonrası inkübasyon süresi uzun bir Kırım Kongo Kanamalı Ateşi olgusu
}

\section{A case of Crimean-Congo Hemorrhagic Fever disease due to tick bite with long incubation period}

\author{
Mustafa TORUN ${ }^{a}$
}

Özel Denizli Odak Hastanesi, Denizli, TÜRKIYE

\section{ÖZET}

Kırım Kongo Kanamalı Ateşi (KKKA) ülkemizde endemik olarak görülen, kene kaynaklı kanama ve ateşle seyreden viral bir enfeksiyondur. Kırım Kongo Kanamalı ateşi olgularında kene teması sonrası inkübasyon süresi 3-10 gün arasında değişir. Enfekte hastanın vücut sekresyonlarıyla sağlıklı bireylere bulaş sonrası inkübasyon süresi daha kısa olup 3-7 gün arasında değişir. Bu yazıda Giresun ilinde ikamet eden, hayvancılıkla uğraşan 26 yaşında bir kadın olguda kene temasından 20 gün sonra gelişen (inkübasyon süresi uzun) KKKA hastalığı sunularak literatür gözden geçirildi.

Anahtar Kelimeler: Kene teması, Kırım Kongo Kanamalı ateş, atipik klinik seyir

\section{ABSTRACT}

Crimean-Congo Haemorrhagic Fever (CCHF) caused by a tick-borne virus is a viral infection which is endemic in Turkey. In CCHF infected cases the incubation period varies from 3 to 10 days after the tick-contact. The incubation period is shorter and varies from 3 to 7 days if the infection caused by the CCHF-infected patient's secretions. In this case report a 26 years old woman, residing in Giresun, engaged in animal husbandry, has CCHF, developed 20 days after the tick-contact (incubation period is longer) is presented and the literature is reviewed.

Key words: Tick-contact, Crimean-Congo Haemorrhagic fever, atypical clinical manifestation 


\section{Giriş}

Kırım-Kongo kanamalı ateşi (KKKA), ülkemizde bazı bölgelerde endemik olarak görülen, ateş ve kanamalarla seyreden sıklıkla kenelerden bulaşan, mortal seyredebilen zoonotik bir enfeksiyondur. Türkiye'de KKKA olguları Sivas, Çorum, Tokat, Yozgat, Gümüşhane, Trabzon, Erzurum illerinde endemik, diğer illerde ise sporadik olarak görülmektedir [1-3)].

Hastalık özellikle mart ayı başından ekim ayı sonuna kadar özellikledenisan-temmuzaylarıarasında kene popülasyonunun aktif olduğu dönemlerde görülmektedir. Ülkemizde hastaların \%70'inde kene teması öyküsü, yaklaşık \%30'unda ise evcil hayvanlarla temas öyküsü mevcuttur [1]. Az sayıda olguda hastanede yatan KKKA'li hastalardan nozokomiyal bulaş şeklinde olgular da bildirilmiştir [2,3]. Hastalığın inkübasyon süresi kene teması sonrası 1-3 gün ortalama 3-10 gün arasında değişir. Enfekte kan veya dokularla temas sonrası inkübasyon süresi ortalama 3-7 gün olup, inkübasyon dönemini takiben hastalık belirtileri ortaya çıkar [1].

Hastalık belirtileri ani ortaya çıkar. Başlangıçta gribal enfeksiyon benzeri halsizlik, miyalji, baş dönmesi, baş ağrısı, boğaz ağrısı ve fotofobi (ışığa duyarııık) görülebilir. Erken dönemde mide bulantısı, kusma ve boğaz ağrısı olabilir; bu tabloya ishal ve yaygın karın ağrısı da eşlik edebilir. Hastada konfüzyon, ajitasyon, uyku hali ve depresyon gibi bulgular da görülebilir. Diğer klinik bulgular; taşikardi, lenfadenopati ve ağız ve boğaz gibi iç mukozal yüzeylerde ve cilt üzerinde peteşiyal döküntüdür. Peteşi, ekimoz ve melena, hematüri, epistaksis ve diş eti kanaması gibi diğer hemorajilere neden olabilir. Genellikle hastalarda hepatit bulguları da saptanır. Hastalığın 5. gününden sonra hepatorenal yetmezlik ve akciğer yetmezliği gibi ciddi komplikasyonlar gelişebilir. KKKA'da ölüm sıklıkla hastalığın ikinci haftasında meydana gelmektedir [1].
Bu yazıda literatürde hayvancılıkla uğraşan 26 yaşında bir kadın olguda kene temasından 20 gün sonra gelişen (inkübasyon süresi uzun) KKKA hastalı̆ı̆ı olgusu sunulmuştur. Hasta destek tedavisi ile tamamen düzelmiştir. Literatürde inkübasyon süresi uzun KKKA olguları nadiren bildirilmiştir $[4,5]$.

\section{Olgu sunumu}

Yirmi altı yaşında Giresun ili Şebinkarahisar ilçesinde hayvancilıkla uğraşan bayan hasta ateş titreme üşüme halsizlik kırgınlık vücut ağrısı baş dönmesi şikayeti ile Şebinkarahisar Devlet Hastanesi Acil servise başvurmuş. Anamnezinden 20 gün önce sol kol dirsek üstünde kene ısırmış, keneyi kendisi çıkarmış ve pansuman yaptırmamış.

Acil serviste yapılan tetkiklerinde lökopeni ve trombositopeni saptanınca ambulansla Prof. Dr. A. Illhan Özdemir Giresun Devlet Hastanesi acil polikliniğine sevkedilen hasta KKKA ön tanısı ile Enfeksiyon Hastalıkları servisine yatıııdı. Kliniğimizde yapılan tetkiklerinde BK: 1250/mm3, nötrofil 780/mm3, lenfosit 390/ mm3, monosit 550/mm3, Hb 11,4g/dl, Hct: 34,5, Trombosit (PLT) sayısı: 106.000/mm3, AST: $33 \mathrm{lU} / \mathrm{ml}$, olarak saptandı. Diğer tetkikleri normaldi.

Hastaya semptomatik destek tedavisi başlandı. Ateşi için parasetamol, oral alımı az olduğu için de sıvı replasmanı yapıldı. İkinci gün ateşi kontrol altına alınan hastanın tekrarlanan testlerinde BK: 980 / mm3, Hb: 11 g/dl, Hct: 33,2, PLT: 89,9/mm3, AST: $55 \mathrm{IU} / \mathrm{ml}$, Ca: 7,2 olarak saptandı. Hastaya sıvı replasmanına ilaveten kalsiyum replasmanı da yapıldı.

Hastanın yatışııın üç ile altıncı günlerinde ateşi ve kanaması olmadı, lökosit sayısı aşamalı olarak yükseldi. Hastanın yapılan tetkiklerinde, üç ile altıncı günleri arasındaki PTT, kan sayımı ve biyokimyasal değerleri Tablo 1'de gösterildi.

Tablo 1. Hastanın yatışının üç ile altıncı günleri arasındaki kan parametreleri

\begin{tabular}{|l|l|l|l|l|l|l|l|l|l|}
\hline Yatış günü & Lökosit sayısı (mm3) & Nötrofil sayısı $(\mathrm{mm} 3)$ & $\mathrm{Hb}$ & Hct & PLT & AST & ALT & LDH & Ca \\
\hline 3. gün & 1880 & 890 & 9.9 & 29,5 & 69.300 & 109 & 59 & 510 & \\
\hline 4. gün & 1100 & 269 & 10.6 & 31,9 & 66.800 & 85 & 60 & 536 & 7,6 \\
\hline 5. gün & 1666 & 530 & 11.1 & 32,8 & 67.300 & 78 & 59 & 527 & \\
\hline 6. gün & 2670 & 839 & 10.4 & 31,4 & 126.000 & 46 & 47 & 484 & 8,2 \\
\hline
\end{tabular}

Yatışının altıncı gününde hastanın kliniği ve kan değerleri normal sınırlara döndü. Hastadan KKKA hastalığı için Refik Saydam Hıfzıssıhha Merkezi Başkanlığı, Viroloji Referans Laboratuarına gönderilen kan örneği sonucunda KKKA-PZR testi pozitif olarak raporlandı. Anamnezi tekrar alınan hastada 20 gün önceki kene teması dışında bir kene teması olmadığı öğrenildi. Olgu yatışının onikinci gününde şifa ile taburcu edildi.

\section{Tartışma}

Kırım Kongo kanamalı ateşi (KKKA) ilk kez 1944 yılında Kırım'da görülmüş ve Kırım kanamalı ateşi adını almıştır. Daha sonra 1956 yılında Kongo'da saptanan kanamalı ateş olgularının Kırım kanamalı ateşine benzediğinin anlaşılması üzerine 1969 yılında hastalık KKKA olarak isimlendirilmiştir. Hastalığın 
etkeni olan virüs Bunyaviridae ailesi Nairovirüs cinsinde yer alır. KKKA ateş ve hemorajilerle seyreden \%5 - 10 arasında mortal seyredebilen zoonotik bir enfeksiyon olup, en sık kene tutunması sonrası gelişir.Türkiye'de ilk KKKA olguları Tokat ve çevresinde 2002 yılında bildirilmiştir. Ülkemizde 2002-2011 yılları arasında bildirilen KKKA olgu sayısı 4576 olup hastaların 230'u hastalıktan ölmüştür. Ülkemizde bildirilen mortalite oranı yaklaşık \%5'dir $(\% 4,5-6,2)[1,2,4]$.

KKKA virüsünü taşıyan başlıca keneler Hyalomma cinsi kenelerdir. KKKA virüsünü taşıyan enfekte kenenin tutulmasını takiben ortalama 1-3 günlük (en fazla 12 gün) inkübasyon sonrası hastalığın belirti ve bulguları ortaya çıkmaktadır. Literatürde inkübasyon süresi uzun olarak bildirilen az sayıda olgu mevcuttur. Kaya ve ark.(5) KKKA tanısı konan 312 hastada yaptıkları çalışmada hastaların 12'sinde $(\% 3,8)$ inkübasyon süresini 12 günden uzun (13-53 gün, ortalama 24 gün) bildirmişlerdir. Koç ve Willke [4] Kocaeli ilinde bahçe işleriyle uğraşan 40 yaşında bir kadın hastada 30 gün önce kene tutunması sonrası hastalığın belirti ve bulgularının geliştiğini bildirmişlerdir. Olgumuz kene tutunması sonrası inkübasyon süresinin 20 gün olması yönüyle Kaya ve ark. [4] ile Koç ve Willke [4]'nin sundukları olgularla benzerlik göstermekteydi.

KKKA olgularında inkübasyon süresinin uzun olma nedenleri; hastanın immunitesi, alınan virüs miktarı ve etkenin bulaş şekliyle ilişkili olabileceği bildirilmiştir $[2,4]$.

Olgumuzun hastanemize geç başvurması, başvuru esnasında kliniğinin hafif ve orta düzeyde seyretmesi nedeniyle olguya ribavirin tedavisi başlanmadı. Olgumuz uygun destek ve semptomatik tedavi ile tamamen iyileşti.

Sonuç olarak, KKKA ateşi ile uyumlu ateş semptom ve bulguları olan hastalarda kene tutunması sonrası inkübasyon süresinin uzun olabileceği akılda tutulmalı ve hastalar KKKA ve komplikasyonları açısından araştırılmalıdır.

\section{Çıkar çatışması ve Finansman Beyanı}

$\mathrm{Bu}$ çalışmada çıkar çatışması ve finansman destek alındığı beyan edilmemiştir.

\section{Kaynaklar}

1. Kırım- Kongo Kanamalı Ateşi. Bulaşıcı Hastalıkların Laboratuvar Tanısı için Saha Rehberi. http://mikrobiyoloji.thsk.saglik.gov.tr/ ums/K/Kirim-Kongo-Kanamali-Atesi.

2. Ergönül O. Crimean-Congo haemorrhagic fever. Lancet Infect Dis 2006; 6: 203-14.

3. Leblebicioğlu H. Crimean-Congo haemorrhagic fever in Eurasia. Int J Antimicrobal Agents 2010; 35 : 43-6.

4. Koç MM, Willke A. Kocaeli'de uzun inkübasyon süreli sporadik KırımKongo kanamalı ateşi olgusu. Mikrobiyol Bult 2012; 46: 129-33.

5. Kaya A, Ergin A, Güven AS, et al. Crimean-Congo hemorrhagic fever disease due to tick bite with very long incubation periods. Int J Infect Dis 2011; 15: e 449-52. 